\title{
Kernos
}

Revue internationale et pluridisciplinaire de religion grecque antique

$10 \mid 1997$

Varia

\section{Neoptolemos at Delphi}

\section{Emilio Suárez de la Torre}

URL: http://journals.openedition.org/kernos/655

DOI: 10.4000/kernos.655

ISSN: 2034-7871

\section{Publisher}

Centre international d'étude de la religion grecque antique

\section{Printed version}

Date of publication: 1 January 1997

Number of pages: 153-176

ISSN: 0776-3824

Electronic reference

Emilio Suárez de la Torre, « Neoptolemos at Delphi », Kernos [Online], 10 | 1997, Online since 12 April 2011, connection on 30 April 2019. URL : http://journals.openedition.org/kernos/655; DOI : 10.4000/ kernos.655 


\section{Neoptolemos at Delphi ${ }^{1}$}

1. The status of Delphi as a political and civic entity was a very particular one $^{2}$. Born as an ordinary village with a small shrine, it developed, very soon after its foundation ${ }^{3}$, into a special complex, conditioned (and ruled) by the neighbouring (or most powerful) states and their interests, and with a majority of population working as servants for the sanctuary. But Delphi was also a community that had its own social and civic organization, a calendar and festivals. The consequence was that Delphi was always between opposite poles: the local traditions and its panhellenic role. The old institution of the phratria, based on kinship bonds, held a strong validity along the centuries, while, as a matter of fact, the private and public life of the Delphians was deeply linked to the history and activity of the sanctuary. Therefore, there was a reciprocal influence between the local and the general trends. An interesting example of this interrelation is the myth and cult complex of the hero Neoptolemos. It is my purpose then to analyse it in the following pages in order to enhance these combination of general cultic and ritual features with other more particular and 'typical' Delphic.

\section{The myth and the cult: a first approach}

The fact that the hero Pyrrhos-Neoptolemos had been buried at Delphi undoubtly needed some explanation. There were some different versions that accounted for the presence of Neoptolemos at Delphi, his violent death and the existence of a tomb of the hero. The most thorough analysis of this myth being

\footnotetext{
1 This article has been made under the general frame of the Research-Programm PB94-1109 of the spanish DGICYT (Ministerio de Educación y Cultura).

2 On the particular status of Delphi see M.A. LEVI, Il mondo di Delfi, in Mélanges Lévêque, I, Paris, 1988, p. 219-228. Despite his opposition to F. DE POLIGNAC's theories on the origins of the poleis (La naissance de la cité grecque, Paris, 1984), he acknowledges that Delphi could befit them. But $I$ think that it is not exactly the same thing to be "una forma realmente tipica d'un potere politico unificante e istituzionale derivante da una 'città santa' che è il polo di una communità umana assai larga" (as he defines Delphi) than to be a polis that emerges as an 'urban aggregate' driven by religious motives or to be a non-urban sanctuary created as a means of increasing the own territory (as he summarizes DE POLIGNAC's theories).
}

3 See C. MORGAN, Athletes and Oracles, Cambridge, 1989, p. 106. 
that of Fontenrose ${ }^{4}$, I will start from his classification of the variants. He established five different groups (to which must be added, as a particular case Euripides' Andromache, a combination of several versions). Four of them described Neoptolemos' death as a consequence of his fight or quarrel against the Delphians: they or an attendant of the temple, or even Apollo, kill him. In the fifth version the killer (or instigator of the death) is Orestes. The motivation of the different actions varies too, as Burkert points out, "according to whether

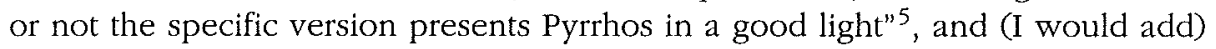
the Delphians as well. So, for instance, version $\mathbf{1}$ (in which Neoptolemos, as he is refused the satisfaction demanded for Achilles' death before Troy, plunders the sanctuary and sets fire to the temple) ${ }^{6}$, gives a violent image of the hero, while his killing is fully justified. Even worst for him is version 2 (Neoptolemos has the exclusive aim of plundering the temple, in order to get means to conquer the Peloponnesos) ${ }^{7}$. On the contrary, version 3 is very positive for the hero, but not so much for the Delphians: Neoptolemos went to the sanctuary to offer a part of the spoils he brought from Troy, but quarreled with the attendants over the apportionment of the meat (and they kill him) ${ }^{8}$. In version 4 (in my opinion derived from version 5), the reason for Neoptolemos visiting Delphi is a very usual one (to ask about the sterility of Hermione), but he becomes angry as he sees the attendants seizing a big portion of the sacrificial meats, and he is then killed with a knife9. One is tempted to say that Orestes' role (version 5) is a

4 J. FONTENROSE, The Cult and Mytb of Pyrros at Delpbi, in UCPCA, 4, 3 (1960), p. 191-266 (see p. 212 f.); hereafter this work will be cited as Neoptolemos. A useful summary of these traditions (on both, myth and cult) can also be found in P. POUlLLOUX - G. ROUX, Énigmes à Delphes, Paris, 1963. For other general surveys of this mythic figure see: P. WEIZSÄCKER, Neoptolemos, in W.H. ROSCHER, Lexikon der Griechiscben und Römischen Mytbologie, Leipzig 1897-1902 (repr. Hildesheim-ZürichNew York, 1993), vol. III, 1, c. 167-176; L.R. FARNELL, Greek Hero Cults and Ideas of Inmortality, Oxford, 1921, p. 311 f.; C. ROBERT, Die griechiscbe Heldensage, Berlin, 19264, p. 1218-1225; K. ZIEGLER, Neoptolemos, in RE, XVI (1935), c. 2440-2462; O. TOUCHEFEU-MEINIER, Neoptolemos, in LIMC, VI, 1 (1992), p. 773-779; for the epic (literary) tradition see: F. VIAN, Recbercbes sur les Posthomerica de Quinhus de Smyme, Paris, 1959 et F. JOUAN, Euripide et les Chants Cypriens, Paris, 1966. More specific litterature will be cited below.

5 W. BuRkERT, Homo Necans, Berkeley-Los Angeles, 1983 (engl. transl. of the German edition, 1972), p. 119 .

6 In this version he is killed: either (a) by a priest called Machaireus or Philoxenides, or (b) by all the Delphic temple servants, or (c) by Apollo (directly or indirectly). Sources: APOLLOD., Epit., 6, 14; EUR., Or, 1655 1657; STRABO, IX, 3, 9 (p. 421); SERV., Aen., III, 332; ps. LIB., Narr., 14; schol. vet. PIND., N. VII, 40 (58); schol. vet. EUR., Andr., 53, 1151. Cf. EUR., Andr., 52 f., 1002 f.; 1106-1108; ASKLEPIADES J. 12, 15, ap. schol. vet. in PIND, $N$. VII, 42 (62), Apollo as instigator of the death: EUR,, Andr., 1147-1149; 1161-1165, 1211 f.; PAUS., I, 13, 9; cf. PAUS., X, 24, 4. Philoxenides as killer: Suid. Chron. ap. schol, vet. in EUR., Andr., 53.

7 He is killed either by Machaireus or by the Delphians. Sources: Anon. ap. schol. vet. PIND., $N$. VII, 40 (58); STRABO, loc. cit.; TrIPH., 640-643; cf. PAUS., X, 7, 1; EUR., Andr., 1092-1095, $1110 \mathrm{f}$.

8 Sources; PIND., Pae. VI, 110-120, N. VII, 33-48; cf. DICTYS, 8, 12; HYG., Fab. 123, 2; schol. vet. PIND., N. VII, 42 (62).

9 Sources: PHEREC., FGrHist F 64 a (ap. schol. vet. EUR., Or., 1655; schol. vet. PIND., N. VII, 40 [58]). 
secondary development (and Hermione's intervention looks like an artificial link between both heroes) ${ }^{10}$. Anyway it also contributes to depict the protagonists of the story under very different lights: it can remove the responsability of the temple servants in the murder; moreover, Orestes is an "apollinean" hero, not alien to Delphic traditions.

All these versions can be reduced to a concise formulation of the myth: Pyrrhos-Neoptolemos was killed in Apollo's temple at Delphi (either by Apollo, or by one or more attendants, or by Orestes -directly or indirectly) and buried in the sanctuary. We have then an epic myth (originated in the frame of the materia epica of the postbomerica) working as aition to account for the existence of the tomb of a hero in the Delphic sanctuary.

As for the cult, the most ancient source that mentions it is Pindar, who explains the death of the hero in the temple as the fulfilment of the fate:

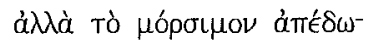

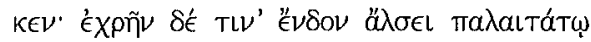

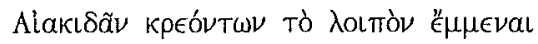

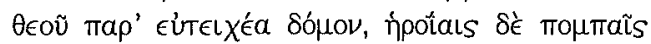

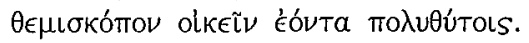

$$
\text { (N. VII, 44-47) }
$$

As usually when a poet alludes to a matter sufficiently known by the audience, he needs not to give any details. The scholiast's ${ }^{11}$ explanation has arousen suspicions, because it reflects some misunderstanding of Pindar's words; but even so it gives interesting information (pace Fontenrose ${ }^{12}$ ): yivetal

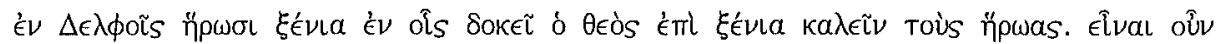

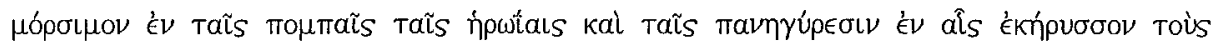

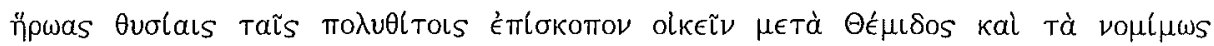

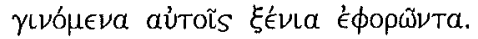

A first problem is to decide whether the plural used by Pindar is a poetic one (due perhaps to the repetition of the ceremony) or it actually means that he was not the sole hero who received these honours. The scholiast follows this

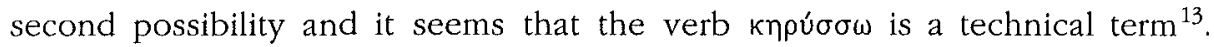

10 The different alternatives (concerning the bridal promise, Neoptolemos behaviour, Orestes role etc. are concisely summarised by FONTENROSE, Neoptolemos, p. 212 . Sources: $l$. Parva fr. 21 Bernabé; APOLLOD., Epit., 6, 14; XENAGORAS ap. schol. vet. in EUR., Andr., 53.; HELIOD., Aith., II, 34; HYG., Fab. 123, 2; SERV., Aen., IIl, 330; DRAC., Orest. Trag., 807-819; cf. Eur., Andr., 995-1006, 1063-1075, 1090-1119, 1241 s.; VIRG., Aen., III, 330-332; DICTYS, 6, 13.

11 Schol. ad PIND., N. VII, 62 and 68a, p. 125-126 Drachmann.

12 FONTENROSE, Neoptolemos, p. 197.

13 This use is close to what we find in the Vitae of Pindar: the poet recieved at Delphi special honours (one could say "heroic") and was invited to the table of the god: a $\lambda \lambda \dot{\alpha}$ kai $\dot{\epsilon} \nu \Delta \epsilon \lambda \phi o i s s$

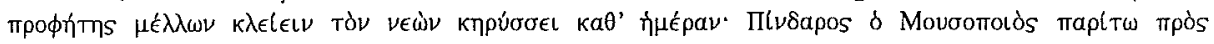




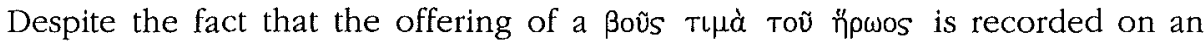
Amphictionic inscription ${ }^{14}$, it does not necessarily mean that the hero was

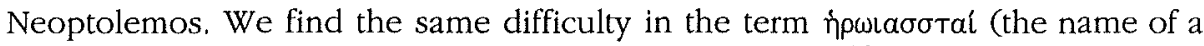
religious organization or thiasos) on a local inscription ${ }^{15}$; the fact that it was placed on a wall of the Cnidian monument might be a case for the identification of this group as worshippers of the hero Neoptolemos, but it can be an association of a more general kind.

As a complementary (though indirect) evidence for Neoptolemos' cult at Delphi, Pindar's Paean VI could be added as well. As I will try to make clear later on, the myth of this poem cannot be explained but in the cultic reality of the sanctuary ${ }^{16}$.

From Pindar we must go on to Pausanias to have some information about the cult (and on the local surviving traditions concerning the hero). He gives us the following indications:

- In the Apollinean temple was exhibited the $\dot{\epsilon} \sigma i l \alpha$ upon which ( $\left.\dot{\epsilon}^{\prime} \phi^{\prime}\right)$ Apollo's priest (iepeús) killed Neoptolemos (X, 24, 4-5). This event is depicted as a punishment or compensation for the murder of Priamos upon the altar of Zeus Herkeios at Troy: this is the reason why Neoptolemos was slain beside Apollos'

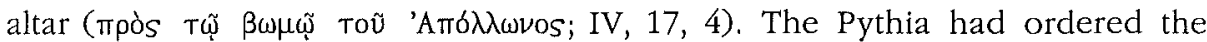
Delphians to kill him (I, 13, 9) ${ }^{17}$.

- Neoptolemos was buried near the temple of Apollo ("turning leftwards from the entrance, as one leaves the temple" says Pausanias): there was a peribolos with the tomb ( $\tau$ dúos) inside (X,24,6). This tomb could not lay far from the Cnidian lescbe, as we may infer from Pausanias' statement that Polygnotos painted Neoptolemos as the only Greek killing Trojans during the fall of the city, "because the whole painting was to be placed above Neoptolemos' tomb" $(\mathrm{X}, 26,4)^{18}$.

- The tomb was honoured (in the time of the Periegetes) every year with an enagismos by the Delphians (X, 24, 6). This enagismos (it seems) was instituted

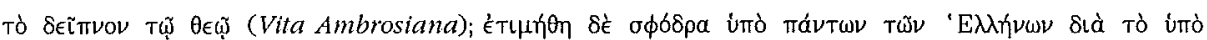

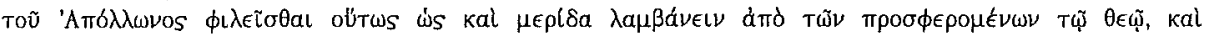

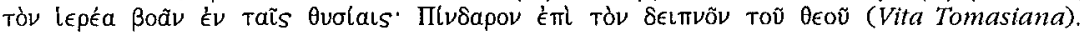

$14 I G, \mathrm{II}^{2}, 1126 ; S I G^{3}, 145 ; C I D, \mathrm{I}, 10 ;$ cf. SEG, XVI, 104, XXIX, 128. This hero is mentioned some

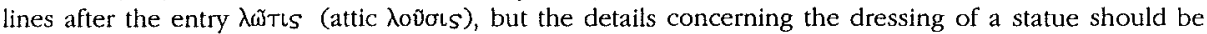
referred to Athena, and not to Neoptolemos (see G. ROUX, in Rayonnement grec. Hommages à Charles Delvoye, Bruxelles, 1982, p. 227-235).

15 Edited first in Fouilles de Delphes, III, 1, 294 and dated ca 380/65 b. C.; it was a lex de usuris placed on a wall of the Cnidian monument.

16 See below 4.2.3.1.

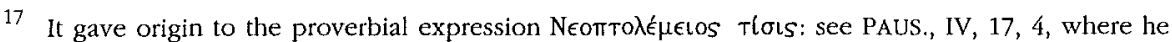
explains it as Tò $\pi a \theta \in \tilde{L} \nu$ ómoĩó

18 I believe that there is a direct relation between this position of Polygnotos' work and Neoptolemos' myth and cult, pace R.B. KEBRIC, The Paintings in the Cnidian Lesche at Delphi and their Historical Context, Leiden, 1983, p. 22-23. 
after the defeat of the Gauls (who attacked Delphi in 279-78 b.C.), to commemorate the aid given by the hero to the Delphians: he, and other heroes as well (Hyperochos and Amadokos, called Hyperborean by Pausanias), fought against the foe under the appearance of terrible warriors. Pausanias adds that before the institution of this enagismos, the Delphians had this tomb év átulia (I, 4, 4).

The third possible evidence is of a more problematic nature. Nilsson ${ }^{19}$ distrusted its value due to its literary character and the difficulties to distinguish the real from the fictional elements in it. I am speaking of the description of the periodical (quadriennial) theoria of the Aenianes included in Heliodoros' Aitbiopica ${ }^{20}$. This theoria was sent, it is said, at the time of the Pythian festival and its participants offered a hecatomb at Pyrrhos tomb (described as enagismos as well). The Aenianes (Theagenes is their arcbitbeoros in this romance) claimed that Achilles was their national hero, because of their ancient Thessalian origin. The details of this event given by Heliodoros are of a diverse nature and include information about female participation, a brilliant procession of boys on horseback, sacrifice and banquet, choruses of girls and enhoplian dances of boys, etc. Such a detailed description might reveal, as Fontenrose stated, "an eyewitness, himself or an informant"21. Very important in my opinion is the abundance of ephebic (and in general, initiatiory, including girls) traits in this ceremony, something to take into account for further reflections ${ }^{22}$.

\section{Some interpretations}

Nearly every scholar who has studied the Delphic cults and traditions has devoted some lines to Neoptolemos, not to speak of the mythologists. It is not my purpose to list them now, but only to select some significant theories and opinions of this century (assuming a certain amount of unavoidable subjectivity in the selection) ${ }^{23}$.

Usener $^{24}$ is the first scholar I will cite. He is the author of a paradigmatic article, often unjustly dismissed. He realised the importance of the epic influence on Delphic rituals. He proposed that in the month Ilaios (in which some ancient

19 M.P. NILSSON, Griechische Feste von religiöser Bedeutung, mit Ausschluß der attiscben Stuttgart, 1906 (repr. Darmstadt, 1957), p. 461-462.

20 II, 34 - III, 6; III, 10.

21 FONTENROSE, Neoptolemos, p. 195.

22 See below 4.2.3.2.

23 I will not dwell now upon A. MOMMSEN's work (Delphika, Leipzig, 1878), because it does not contain properly an interpretation of the myth. It will often be cited later à propos of the cults and festivals.

24 H. USENER, Hellige Handlung, in ARW, 7 (1904), p. 281-339 (= Kleine Schriften IV, LeipzigBerlin, 1913, p. 422-467; I will follow this pagination). 
sources dated the fall of Troy) was celebrated the ennaeteric Septerion (he used this form), formerly called Ilaia, in which the destruction of the hut of a daimon by the young Apollo was performed. The reason for the presence of Neoptolemos at Delphi was that he fits the general category of a "heroisierte Gott" (and his role in the Trojan saga). For the same reason Orestes should be a 'Doppelgänger' of Dionysos. The death of Pyrrhos and the "sacred actions" acted in his festival belong to the pattern representing the seasonal change from summer to winter (the Ilatos is an autumn month). As for the epic Doloneia, it would be inspired by the same ritual tradition (because Apollo is the wolf-god). The recurring motif is the furtive robbery (also found in the Aesopos' legend) ${ }^{25}$. The actual aim of these ritual actions was to attract the rain after the dry summer.

In 1954 Defradas $^{26}$ studied the myth and cult of Neoptolemos in the frame of his theory on the propagandistic policy of Delphi. As it will be the case for many scholars in the following years (due to the optimistic opinions of the excavators $^{27}$ ) he postulated that Neoptolemos' cult had superseded an ancient Mycenaean hero cult. He launched the thesis of the existence of a (lost) Delphic poem exploiting Neoptolemos role for propagandistic aims, A Delphic poet would have composed it to account for the origin of the temenos; Neoptolemos was considered a good character to play the role of Apollo's foe: he was a Thessalian, a people seen as enemy for some time ${ }^{28}$, and the historical origins of this enemity go back to the times of the pretensions of the Anthela Amphyctiony on Delphi's treasures. Some artists would have contributed to this Delphic propaganda. Pindar, by presenting the hero's death as an expiation, tries to justify so this tradition, whereas Polygnotos' painting would have been the evidence of the existence of a Delphic version of the Iliou Persis.

In 1960 the extensive analysis of Fontenrose appeared. Although nowadays some of their opinions and hypothesis may seem unconvincing or plainly wrong, it deserves attention, not the least because of the wide range of subjects the author studies. His most significant conclusions are the following ${ }^{29}$ :

- Ziegler's opinion (that no cult of Pyrrhos ${ }^{30}$ can be aduced before 278 b.C.) does not pay sufficient attention to Pindar's witness, a good evidence for the cult.

25 For this legend see below 4.1.

26 J. DEFRADAS, Les thèmes de la propagande delphique, Paris, 1954, p. 146-156.

27 He refers to L. LERAT, Fouilles de Delphes (1934-1935): Rapport préliminaire, in RA ser. 6, 12 (1938), p. 183-227, and E. BOURGUET, Les ruines de Delphes, Paris, 1914, p. 195 f.

28 He thinks (p, 155) that Paean VI reflects this hostility, although Pindar Nemean VII would indicate a "reconciliation".

29 I select now only those regarding strictly the problem of myth and cult of Neoptolemos.

30 Fontenrose chose the form Pyrros, but I have preferred this more usual transcription, to homogenise it along the text. 
- This cult superseded an ancient Mycenaean heroic cult. Pyrrhos would be the name of this ancient hero, later replaced by the epic one Neoptolemos.

- The episode of Pyrrhos' help to the Delphians has two foregoing models. One is the assistance given to them by the heroes mentioned by Herodotos ${ }^{31}$ (Phylakos and Autonoos), when Persian troops arrived in the sanctuary. The other is the attack of the legendary Phlegyans, whose king set fire to the temple and then the Phocians were defended by Apollo and the Phlegyans punished ${ }^{32}$. As for the former one, Fontenrose believes that Herodotos omits the name of Pyrrhos because this hero and Phylakos are the same.

- Neoptolemos and Achilles are "one and the same Thessalian hero or god"33 (he lists 21 shared features). More precisely both represent "an ancient Thessalian deity of summer, rain and growth (..), opponent of his counterpart, the deity of winter, drought, and death"34.

- That deity is represented in the ancient Delphic myth by Machaireus, but he was later replaced by Orestes, the "winter daimon". As a wild "mountainer", Orestes must be identified with Dionysos as well. For the same reason, Python must be put in the same rank of opponents, as a form of the "Winter King"35.

- The primitive antagonists of Achilles-Neoptolemos belong to Thessalian mythology: they were Kyknos and Eurypylos (in fact a equivalent to Hades).

- Parallels like that of the combat of Melanthos with Xanthos and others suggest that we have here another example of a combat myth, this time of the 'fair' (Pyrrhos) against the 'black'. Moreover, the comparison with other stories containing the "brothers' quarrel theme" leads to the conclusion that "the earliest Delphic myth, then, was a story of two brothers, the Fair and the Dark, who fought for the possession of a sister and were alternatively successful in winning her" 36 .

31 The description is that of VIII, 31-39.

32 PAUS., IX, 36, 1-3. The link between the Phlegyan and the Persian legends could be found in the account of the attack of Encheleis and Illyrians upon Delphi (cf. HDT., IX, 42, 3-43, 1). He sees also a link between King Elatos and Pyrrhos-Neoptolemos (p. 204-205).

33 Neoptolemos, p. 207.

34 Neoptolemos, p. 210. See, of the same author, Pytbon: A Study of Delpbic Myth and its Origins, Berkeley, 1959, p. 399-401 (hereafter Python).

35 See, for instance, p. 229: "The Delphic Winter King, whom we may identify with Machaireus and Orestes as slayer of Pyrrhos, was certainly not called Dionysos or Python at first. He was identified with Dionysos probably when the worship of the god called Dionysos spread over Hellas, taking over or adding to itself the cults of many local heroes and daimones". Note that, if the opponents to Phylakos-Pyrrhos-Neoptolemos are those of the series Machaireus-Orestes-DionysosPython, then we must add to the first list the name of Apollo, and therefore killer and victim become the same.

36 Neoptolemos, p. 254. 
- Finally, he states that "the myth of Pyrrhos and Machaireus-Orestes was overshadowed at Delphi by the myth of Apollo and Python, though never forgotten"37.

Five years after Fontenrose $M$. Delcourt published her monography on Pyrrhos and Pyrrha ${ }^{38}$. The pages dedicated to the Delphic hero were not a systematic analysis of the myth, but only a group of reflections on the significance of this figure and its cult. Once again we find the hypothesis that Pyrrhos replaced an ancient Mycenaean daimon, but it is his name (and specially the Homeric form Pyres) what draws the attention of the Belgian scholar. She also accepts that Pyrrhos is the name of the hero in the Delphic tradition, whereas Neoptolemos is the epic form. But she observes that this double naming is a peculiar trait of the initiatory rites (the new name being a symbol of the new status). Also the links she establishes with Achilles are of a different nature from those analysed by Fontenrose: It is the name what is explained by the biography of the father ${ }^{39}$. She analyses the evolution of the image of the hero ${ }^{40}$, subordinated to the purposes of the Delphic clergy and to historical events, and the particular ambiguity (marked by a sequence hostility-reconciliation) of the relationship between Apollo and Neoptolemos (this hostility being an outcome of the replacement of Pyrrhos by the "new" god).

The contribution of I. Chirassi ${ }^{41}$ focuses on the dichotomy theos/heros, and is based on the conflict between Achilles and Apollo. As for Neoptolemos ${ }^{42}$, she emphasises his position as victim of Apollo's will and the function of this myth as aition of the presidency of the Aiakides over the themiskopia of the heroic xenia. Theology and politics go together in this case; the relations between the Thessalian league and the Amphictiony of Anthela must be taken into account, as well as those between Delphi and Thessaly in general (see, for instance, the myth of the purification of Apollo in the Tempe valley). The meaning of the myths involving Achilles-Neoptolemos and Apollo must be searched in its way of integrating the hero's role in the new polytheistic system and of underlining the differences between heroes and gods, mortals and inmortals. Their confrontation is easily explained in the theological frame developed in the homeric Hymn to Apollo, where the evolution from disorder to order is emphasised. In this sense Achilles and Neoptolemos are aligned with

37 Neoptolemos, p. 257.

38 M. DELCOURT, Pyrrbos el Pyrrba, Paris, 1965, p. 31-53.

39 Cf. p. 336-337.

40 An interesting remark (criticising Ziegler) is that the heroic status has nothing to do with morality (p. 38).

41 I. ChIRASSI-COlOmbo, Heros Achilleus - Theos Apollon, in B. GENTILI - G. PAIONE (eds.), $I l$ Mito Greco. Atti del Convegno Internazionale, Urbino, 7-12 Maggio 1973, Roma, 1977, p. 231-269.

42 Cf. p. 240 f. 
the drakaina. But the mythical hostility belongs to the past and is exactly the reverse of the later historical reality, as can be seen in the heroic ritual.

G. Nagy ${ }^{43}$ remarks the exceptional nature of Neoptolemos cult at Delphi if compared with hero cult in general: his status trascends the typical one (polis hero) and even he "is more of a Panhellenic figure by virtue of being Hero of Delphi" 44 . Nagy's approach shares some features with the preceding works, but he stresses some points concerning the epic tradition and the sacrificial perspective. He observes that the thematic (and lexical) level of the myth fits well the ritual of the theoxenia. He analyses the close parallel of the account of the Vita Aesopi and, following the etymological connections of the term dais, he reexamines some epic passages where it has a significant value in connection to the figure of Achilles. In contrast with other scholars, he sees an important difference between Achilles and Neoptolemos, namely the fact that the sacrificial elements pervade the story of Pyrrhos (depicted with more savage traits), whereas that of Achilles has a more stylised character. He ends with some interesting remarks on $O d$., VIII, 72-82, a scene that links Achilles-Delphi-dais and quarrel, and that could be appropriate as "an opening Strife Scene for motivating the eventual death of the main hero who undertook the enterprise" 45 .

\section{Trying to contribute to the analysis}

\subsection{General remarks}

In my opinion, from a methodological point of view, and in order to work on a firm basis, any analysis of these traditions must take on account the following principles (that summarize some of the achievements of previous researchs and add others of my own):

- First of all, I suggest that it must be studied as a myth and cult complex with a religious and social function at the same time, that requires a special interpretive pattern. I propose to consider the cult in the frame of the other Delphic festivals (Pythian, theoxenies, stepterion, etc.) and to emphasise the interrelation between both, myth and cult.

- The characteristic features of this complex show what we could call its "environment adaptation". On the one hand it is a myth on sacrifice ${ }^{46}$, but more

43 G. NAGY, The Best of the Achaeans. Concepts of the Hero in Archaic Greek Poetry, Baltimore, 1979, p. 118-141 (Chapter 7, "The Death of Pyrrhos").

44 P. 120.

45 P. 141.

46 Cf. BURKERT, op. cit., p. $116 \mathrm{f}$. 
exactely on Delphic sacrifice ${ }^{47}$. Moreover it is a sacrifice in which the worshipper becomes the victim, and not an irrelevant one, but a hero killed (directly or indirectly) by the god (a well attested motif) ${ }^{48}$. It is also a myth on a hero who, having showed formerly his hostility against the people of the country or polis, becomes the defender and protector of that place after bis death (Neoptolemos is first a themiskopos of the rituals and later a warrior against the enemies) ${ }^{49}$. But there is here an important difference with regard to other myths of this kind (as $\mathrm{Nagy}^{50}$ has observed): he attacks a panbellenic sanctuary and fights against a god. On the other hand, the peculiar traits of both, myth and ritual, make it necessary to study this complex as a heroic cult (albeit especial ${ }^{51}$ ), without dismissing its functions and meaning. The common opinion that the origins of this myth cannot antedate the 7 th century is plainly reasonable, as well as the assumption that it belongs to a historic phase, when these epic heroes were being consolidated as models, among other functions ${ }^{52}$. I

47 See NAGY, op. cit, passim; M. DETIENNE - J. SVEnBro, Les loups au festin ou la cité impossible, in M. DETIENNE - J.-P. VERNANT, La cuisine du sacrifice en pays grec, Paris, 1979, p. 215 237 (see p. 234); R. SEAFORD, Reciprocity and Ritual, Oxford, 1994, p. 48.

48 See M. VISSER, Worbip your enemy: Aspects of the Cult of Heroes in Ancient Greece, in HThR, 75 (1982), p. 403-428 (for Pyrrhos/Neoptolemos, p. 409 with n. 23); the motif is analysed in the case of heroines by J. LARSON, Greek Heroine Cults, Madison, 1995 (with allusions to Pyrrhos in p. 110-111 and $116 \mathrm{f}$.). Some remarks on antagonism in myth that becomes a convivence in the cult can be seen in NAGY and BURKERT (op. cit. above).

49 It is too a typical motif in legends of heroes (Eurystheus). On this bloody side of the heroes see A. BRELICH, Gli eroi Greci. Un problema storico religioso, Roma, 1958, p. 255-256.

50 NAGY, op. cit., p. 119-21.

51 I fully agree with E. KEARNS' statement that "it is convenient to consider together the spatial and temporal aspects which link the activities performed in the hero-sanctuary with a wider sacred and civic canvas" (Between God and Man: Status and Function of Heroes and Their Sanctuaries, in Le Sanctuaire Grec, Fondation Hardt, Vandoeuvres-Genève, 1992 [Entretiens sur l'Antiquité Classique, 37], p. 65-99, cite from p. 77), but it is also true that Neoptolemos cult does not fit some of the usual functions and features of the hero cults of the poleis (as can be seen by applying her description to this case). See also the following footnote.

52 I will cite again KEAkNS (this time from The Heroes of Attica, London, 1989 [BICS Suppl., 57], p. 137): "The hero is as diverse and multi-faceted as the society of which he is a part". As a matter of fact no rigid outlook has reached to explain satisfactorily this phenomenon. After E. ROHDE's Psycbe. Seelencult und Unsterblicbkeitglaube bet der Griecben, Leipzig-Tübingen, 1898 (repr. Darmstadt, 1974; see part I, p. 146-200 of this edition), and his analysis of the heroes as 'Geister Vestorbener', most scholars have enhanced the importance of their diversity. So, for instance, L.R. FARNELL, op. cit., who studies Neoptolemos under the heading 'epic heroes', p. 280-342 (p. 311 f.) or A. BRELICH, $o p$. cit. (but following a different method). Something similar has happened in more recent times with the polemics "Homer us. polis development" as main cause for the origins and evolution of the cult. Compare J.N. ColDSTREAM, Hero-cults in the Age of Homer, in JHS, 96 (1976), p. 1-12 with A.M. SNODGRASS, Archaic Greece: The Age of Experiment, London, 1980, p. 38-40 and An Archaology of Greece, Berkeley, 1987, p. 160-61, or with Th. HADZISTELIOU-PRICE, Hero-cult and Homer, in Historia, 22 (1973), p. 129-44 and Hero-Cult in the 'Age of Homer' and Earlier, in Arktouros. Hellenic Studies presented to Bernard M.W. Knox, Berlin-New York, 1979, p. 219-228; and then see C. BÉRARD, Récupérer la mont du prince: Héroisation et formation de la cité, in G. GNOLI - J,-P. VERNANT, La mort, les morts dans les sociétés anciennes, Cambridge, 1982, p. 89-105, or to DE POLIGNAC, op. cit., p. 127-151. In turn R. PARKER, Athenian Religion, Oxford, 1996, p. 39 (following 
am not siding with the defenders of the theory on the hero cult as originated from the epic tradition (I would rather share the opinion of those who defend a complex origin), but I dare to say that the success of this myth in a Delphic milieu is due to these main reasons:

a) The nature of this particular hero, who shares so many features with the father: he is a dreadful warrior, but presents some epbebic characteristics ${ }^{53}$.

b) The Aeacid lineage had some advantages: Thanks to Homer they are panbellenic heroes, but Thessaly, Aegina, and the Epirus could claim their rights at any moment.

Moreover, Neoptolemos' myth shares some features with the story of Aesop, who was killed (a katakremnismos) by the Delphians, falsely accused of having stolen a golden cup from the temple's offerings ${ }^{54}$ : the truth was that he had ridiculed them for the way they took away their portions from the sacrifice victims. The god sent then a plague, that did not cease till the Delphians erected an altar and dedicated a heroic cult to Aesop. Both stories have been interpreted as representative of a pharmakos pattern ${ }^{55}$. I would agree a priori with this interpretation, but only provided that some important differences be acknowledged as well, thinking of the true historical nature of Neoptolemos' cult. The similarities come from the narrative pattern, but it does not mean that the cult of Neoptolemos was originated in an ancient pharmakos rite. And yet the point is that both stories link both figures to the Delphic religious ideology.

Dwelling upon other traits of the myth, I want to point out that Fontenrose analysis, accepted sometimes by scholars without much criticism, has some unsatisfactory aspects. First of all, the myth is conceived exclusively as the result of the concretion in a narrative pattern of some religious beliefs and archetipal schemes (the explanation of seasonal changes as the fight of the summer -fairdaimon against the winter or dark one, etc., in the line established by Usener) and presuposes some chronological strata: an ancient (Mycenaean) combat myth (Pyrrhos us. Orestes) replaced later by the epic figures and overshadowed by another combat myth, this time that of Apollo against Python. This recon-

KEARNS, op. cit.) has argued that we should redefine the problem, focusing on "the crystallization of the category of heroes". He states very cleverly the problem in these terms: "The more one considers the diversity of the political contexts in which hero-cults emerged up and down the Greek world in the eighth century, the harder it becomes to find a socio-political explanation of any simple type" (ibidem).

53 See J. BREMMER, Heroes, Rituals, and the Trojan War, in SSR, 2 (1978), p. 5-38, but contrast the criticism of H. VERSNEL, What's Sauce for the Goose is Sauce for the Gander: Myth and Ritual, Old and New, in L. EDMUNDS (eds), Approaches to Greek Myth, Baltimore-London, 1990, p. 25-90 (55-57).

54 See B.E. PERry, Aesopica, test. 25-26 (and $c f$. 45-8) and the interpretation by F.R. ADRADOS (from a literary outlook), The 'Life of Aesop' and the Origins of Novel in Antiquity, in QUCC, N.S. 1 (1979), p. 93-112.

55 So A. WICHERS, Aesop in Delphi, Meisenhein am Glan, 1961, p. 31-43 (for Aesop as pharmakos) and 43-49 (for Aesop and Neoptolemos); cf. J.-P. GUÉPIN, The tragic paradox, Amsterdam, 1968, p. 7879. 
struction is based merely on presumptions without any real support. It can be submitted to the same criticism as the "succession myth" 56 , but with a great difference: there was no "myth of the previous hero" at all. Even the alleged fact that there was actually a Mycenaean tomb, that could have contributed to the origins of the cult and myth, is nowadays far from being demonstrable. The identification of the precinct $\mathrm{n}^{\circ} 507$ with the peribolos of Neoptolemos is being now very seriously questioned ${ }^{57}$ and (more important) the pithos found inside, full of black sand and fat from animal bones, formerly identified with a botbros, "has no parallel in the cultic contexts of the Mycenaean period"58.

\subsection{The ritual frame}

\subsubsection{The Labyadae inscription}

Unfortunately we have no thorough description of the Delphic festivals; yet we dispose of a good amount of data of the heortological panorama, to which a precious source can be added: the inscription of the cippus of the Labyadae ( $c a$ 400 b.C. $)^{59}$. I have not the purpose of giving now a detailed description of all the Delphic celebrations, but only to dwell upon their most important features, function and meaning. I want to point out the following aspects of the Labyadae inscription:

- This phratria celebrated an annual festivity, áté $\lambda \lambda a \iota$, in the month Apellaios, for which some special offerings and victims, in accordance with the rules here established, are required. The offerings are classified in three groups:

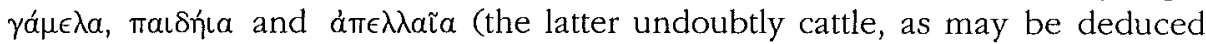

56 See Ch. SOURVINOU-INWOOD, "Myth as History: The Previous Owners of the Delphic Oracle", in "Reading" Greek Culture, Oxford, 1991, 217-43 (a revised version of the contribution published formerly in J. BREMMER [ed.l, Interpretations of Greek Mythology, London, 1988 ${ }^{2}$, p. 215-241).

57 See J.-F. Bommelaer, Guide de Delphes, I : Le Site, Paris, 1991, p. 200. The hypothesis that this tomb would have been placed in the massif $n^{\circ} 503$, at the portic of Attalos I (see Ibid., p. 195), seems not very solid. I think that it is often forgotten the indication by Pausanias that, in his time, the tomb was very close to the Cnidian lesche (see supra...). On the other side (though it cannot be used as archaeological evidence), some versions of the myth state that the hero was buried into the threshold of the temple (for example, PHEREc., FrGrHist, 3 F 64 [= schol. ad EUR., Or., 1655a]).

58 So S. MÜLLER, Delphes mycénienne : un réexamen du site dans son contexte régional, in J.-F. BOMmelaEr (ed.), Delphes. Centenaire de la "Grande Fouille" réalisée par l'École Française d'Atbènes (1892-1903) [Actes du Colloque Paul Perdrizet, Strasbourg, 6-9 novembre, 1991], LeidenNew York-København-Köln, 1992, 67-83 (p. 80): this a very different question of that of the continuity, as can be seen in this same work (from an archaeological point of view the gap is becoming narrower, though there is still a lacune of one century at least).

59 I have worked on the edition and commentary published by G. ROUGEMONT, Corpus des Inscriptions de Delphes, I. Lois sacrées et règlements religieux, Paris, 1977, p. 26-85. The relevance of this document for the study of the public banquets has been recently stressed by P. SCHMITT-PANTEL, La cité au banquet. Histoire des repas publics dans les cités grecques, Rome, 1992, p. 81-83 (with an analysis of the similitudes with the apaturiae) and 90-93 (on the tboinai nomimoi). 
from the verb ä $\gamma \in(\nu)$. Burkert ${ }^{60}$, following the interpretation of Homolle ${ }^{61}$, has emphasised the relevance of this witness as a case for a Delphic 'Ephebenfest', close to the attic Apatouria (where we have a sequence of offerings $\gamma a \mu n^{\prime} \lambda \iota^{-}$ $\mu \in \tilde{L} \sigma \nu^{-\kappa o u ́ p \in(o v), ~ a n d ~ t h e r e f o r e ~ w i t h ~ t h e ~ m e a n i n g ~ a n d ~ f u n c t i o n ~ o f ~ a ~ " F e s t ~ d e r ~}$ Volljährigkeit, des Übergangs vom maĩs zum

- The swearing formula of the tayol includes these three gods: Apollo, Poseidon phratrios and Zeus patroios. They are invoked as gods of the "clan".

- The inscription includes some prescriptions on burial customs, strictly preventing from any mourning or public lamentation ${ }^{62}$.

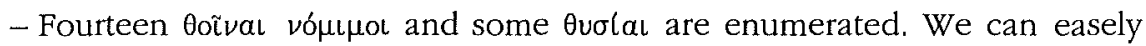
locate the thoinai in the months of the Delphic calendar when both names (that of the feast and that of the month) are identical. Some others mentioned in that text are not so easy to place, but the chronological order of the sequence is a good help ${ }^{63}$. As for the thysiai, the months of the two first are given in the text ${ }^{64}$, and then follows the prescription to celebrate the other $\kappa a \tau^{\prime}$ Tàv üpav.

Whatever the solution could be, the information we actually have allows us to appreciate that the arrangement of the Labyadae ceremonies along the Delphic calendar is far from being an arbitrary one (an appreciation that could be extended to the whole calendar as such). The New Year festivity falls into the Apellaios month. The beginning of the year is marked out by the events that underline the renewal and the cohesion of the society, as well as by the timai for the main local gods. The Apellai mark the acceptance of youth in the adult society, and a thoina of the phratria is prescribed. But the other important Delphic god, Dionysos, is not forgotten: he is honored with a thysia. The next month, Boukatios, is the turn of Zeus Patroos and Apollo, who receives the firstfruits; in the same month the Labyadae have a nomimos thoina (D.3/4) and

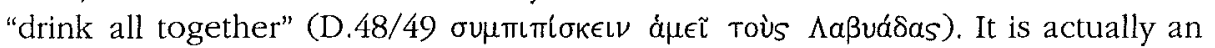
impressive cumulation of celebrations of this phratria, not to speak of the panhellenic festivals that, as the Pytbia, every four years took place in this month.

60 W. BURKERT, Apellai und Apollon, in RhM, 118 (1975), p. 1-21 (see p. 10).

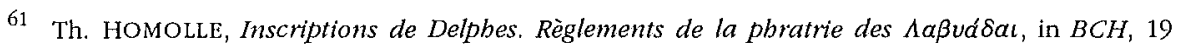
(1895), p. 5-69

62 These prescriptions appear to go further than, for example, the Solonian legislation on these matters. They aim not only to forbid excesive expenses, but to constrain the mourning: perhaps the apollinean religion influenced this tradition.

63 Delphic months and their homonymous and/or dated feasts are: 'A $\pi \epsilon \lambda \lambda a$ Ios ('A $\operatorname{c} \epsilon \lambda a \mathrm{~L}$ ),

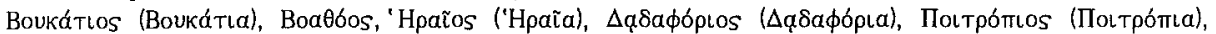

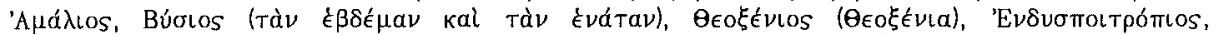

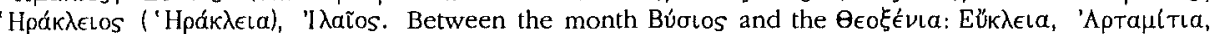

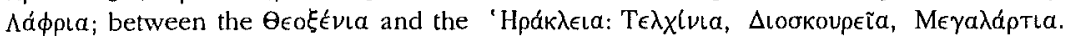

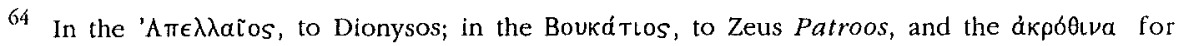
Apollo. 
No indication of ritual is prescribed for the Boathoos month, but if its name preserves some hint of the contents, it could be a good candidate for the festivals of the "defender heroes" (though not the only one) ${ }^{65}$. The fourth month is that of Hera (it includes a beraia) ${ }^{66}$ and then follows the winter cycle (that is, the Dionysiac months): torch processions (Dadaphorios), as well as the propitiation of the negative daimones (Poitropios) ${ }^{67}$ fit well this period ${ }^{68}$. The birth and arrival of Apollo is commemorated in his great month, Bysios (with two thoinai $)^{69}$, but Artemis also receives a good amount of timai under three different dedications corresponding to the feasts named Eucleia, Artamitia, and Laphria $^{70}$. The next month (Theoxenios) other gods are invited (so, for example, Leto, as we know by Atheneus) ${ }^{71}$; it appears as a feast to welcome the return of the gods ${ }^{72}$ and is also linked to the dead cult ${ }^{73}$. The following three thoinai (those of the Endyspoitropios month) are not very difficult to explain. The Telchines (if the reading Telcbinia is right) ${ }^{74}$ are associated to the mythology of Poseidon (an important deity in the local traditions of the 5th century). A cult of the Dioscuri is now corroborated by the new reading of an inscription (more exactely two: they are engraved on the bases of the statues of both Anakes $^{75}$ ) and, as Faure points out ${ }^{76}$, even from an astrological point of view this feast has

65 Cf. MOMMSEN, op. cit. (n. 23), p. 230; but he followed this reading of PIND., $N$. VII, $32-34: \ldots$

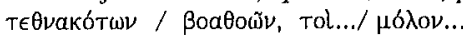

66 A month devoted to Zeus's wife makes more sense if we assume that the beraia aimed to appease the jealousy and eagerness of the Goddess (who, as is shown in the Homeric Hymn to Apollo and in other later sources, tries to prevent Apollo's birth). The theory defended by J.V. O'BRIEN (The transformation of Hera, Boston, 1993, p. 104-105), who (following J. FONTENROSE, Pytbon, op. cit. [n. 34], Berkeley, 1959, p. 119, 377-78) states that Hera could be identified with the Delphic Herois (and so she is the foster mother of Typhon-Python), would allow to go further in this direction.

67 The corresponding Athenian month is Poseideon, but "es ist vorschnell, daraus zu schliessen, daß es ein Poseidonfest sei " (NILSSON, op. cit. [n. 19], p. 470, n. 1, criticising HOMOLLE, art. cit. [n. 61], p. 66).

68 We know nothing of the Amalios month. MOMMSEN, op. cit. (n. 23), p. 143 and 279-80 speculated with the possibility of a festival for Hestia and a theogamia in this month, but only on comparative reasons (the Athenian equivalent is Gamelion). Note that if the name has something to do with the "harvest", then it makes no sense in winter.

69 The seventh and the ninth of the month. It is a festivity of the theophaneia type.

70 NILSSON, op. cit. (n. 19), p. 238 says that "bei den Eukleia wurden Opfer für die in das Geschlecht einzuführenden Neuvermählten und Neugeborenen dargebracht", with reference to this inscription, but there is not much support for this idea.

$71 \mathrm{IX}, 372 \mathrm{a}$.

72 MOMMSEN, op. cit. (n. 23), p. 303 defines this celebration this way: "Der Grundsinn des Theoxenienfestes war, dass der abwesenden Götter, jetzt wieder in das Land kommend, sich bei Speise und Wein wohl sein liessen ands den Tischen der Menschen".

73 See infra, 4.2.3.1.

74 The former reading, Tracbinia, is now abandoned.

75 P. FAURE, Les Dioscures à Delpbes, in $A C, 54$ (1985), p. 56-65.

76 Ibid., p. 64. 
a justification: it is the middle of the spring, coinciding with the rising of Gemini ${ }^{77}$. As for the Megalartia, assuming that this feast ("of the big loafs") may be assimilated to the Thessalian homonym, it must be assigned to the Demetriac cult, what is in accordance with the season of the year (may-june nowadays). As for the Heracleia, the bonds that link Heracles to Delphi are well known, and the nearness of Boeotia may have had some influence ${ }^{78}$.

\subsubsection{Some data from other sources}

The main characteristics detected in the Labyadae inscription (I mean: 'phratriarcal' and initiatory traits, as well as propitiation of gods and heroes, without losing the connection to the year cycle, etc.) are even more apparent in some of the ennaeteric rituals, despite a probable secondary evolution. First of all, they are preserved in the Stepterion, but a possible epic influence and the final connection to the Pytboctonia myth have caused a reinterpretation of the primitive function. Scholars have postulated different solutions to account for the nature of this ritual, preserved by very few sources ${ }^{79}$. Some of them have analysed it basically as a 'Sühnungsfeste'. Nilsson stressed that the relation to the pythoctonia was a secondary (and artful) link ${ }^{80}$. An important shift in the research was the introduction of an initiatory outlook ${ }^{81}$. In this trend the deep analysis of Brelich ${ }^{82}$ was a watershed. In my opinion, his most important contributions are to have distinguished three primarily independent rituals, that eventually coalesced (the ceremony of hut-burning, the daphnephoria to

77 The presence of the Dioscuri may be justified by other reasons, as I will argue below.

78 So NILSSON, op. cit. (n. 19), p. 448. The last month Ilaios has no feast; for USENER (see above) it was the month of the stepterion, because the fall of Troy was dated by some historians in the equivalent athenian Thargelion.

79 On the Stepterion in a strict sense the sources are PLUT., Qu. Gr, 293c and EPHOROS apud STRABO, IX, 3, 12); for the daphnephorikon to Tempe see PLUT., De def. orac., 418a-d, and AEL., V.H., III, 1 .

80 Th. SCHREIBER, Apollon Pytboktonos, Leipzig, 1879, advanced some interesting ideas on the antiquity of the elements of this ritual and its variing relation to the Pytbia and the Tempe procession. J. HARrison, Prolegomena to the Study of Greek Religion, Cambridge, 1903 (repr. New York, 1959), p. 113-114 interpreted it as undoubtly 'kathartic'. NILSSON, op. cit. (n. 19), p. 156 explained this way the reason for the assimilation of these rites: "Die Drachentötung hat zwar nicht eine rituelle Darstellung in dem Septerion gefunden; aber in der alten Fluchtzeremonie drückt sich ein Gefühl der Schuld aus, und eben dieses Gefühl hat die Anknüpfung an die sühneheischende Drachentötung leichter gemacht". That Stepterion and Pythoctonia were linked in a late period (not before the 4th century) was proposed by W.R. HALLIDAY in his commentary to PLUT., Qu. Gr., 293c (Plutarch's Greek Questions, Oxford, 1928, p. 70-71).

81 Cf. H. JEANMAIRE, Couroi et Courètes, Lille, 1939, p. 387-460. But the reluctance against this model persisted longtime: see FonTENrose, Pytbon, op. cit. (n. 34), p. 434-464, where he relates this celebrations to the Babylonian New Year festival.

82 A. BRELICH, Paides e Parthenoi, Roma, 1969, p. 387-428. See now W.D. FurLEY, Studies in the Use of Fire in Ancient Greek Religion, Salem, 1988, p. 172-179, who interprets the complex DoloniaTempe procession-return to Delphi as "basically an initiation rite of the Delphic Labyadae", while rejecting the kathartic aim (but his bibliography has amazing omissions). 
Tempe, and the pytbia) and to have designed a historical development of this process (the key moment is the new religious and political frame of the first decades of the 6th century b.C). Regarding the pytbia, we are well informed on this festival only from 582 b.C. on ${ }^{83}$; but every assumption about its origins and development previously to this date falls in the field of sheer speculation. For the Greeks it was vinculated to the dragon killing by Apollo, and we should not lose sight that at first it was ennaeteric and that there was no sports competition. The rest of the ennaeteric cycle preserves a more agrarian meaning, related to the material subsistence of the people, although without losing its purificatory (or, better, evil-averting) function: this is the case of the Charila or even of the Herois, though the latter has a mysteric compound inherent to the cycle of death and rebirth ${ }^{84}$.

\subsubsection{The literary evidence}

\subsubsection{Pindar's Paean VI (and Nemean VII)}

As I have said above, this paean has an exceptional value to get a precise idea of the meaning of the cult of Neoptolemos at Delphi. Fortunately we are well informed on the occasion for singing this poem: from lines 60-61 we know that it was a theoxenia to which many attendants from the whole Hellas had arrived or, at least, they felt represented in some way (1. 62). A scholium precises that the main target of this celebration was to pray for the welfare of the Greeks during the year ( $\epsilon$ inTepia), until the next theoxenia. ${ }^{85}$ In fact the mythic origin of the festival was a miraculous intervention of Zeus (Helanios) in a drought time, yielding to a prayer made by the Aeginetan hero Aiakos ${ }^{86}$. But, though this is the aition for the prayer, and an important reason to understand the presence of the Aeginetans in the celebration, as well as the Aeginetan allusions of the poem, it is also an unsatisfactory explanation of other aspects.

83 A brief but substantial and precise account of the origin and development of this festival can be found now in B. GENTILI (et alii), Pindaro. Le Piticbe, Fondazione Lorenzo Valla, 1995, p. XXIII$\mathrm{XXXV}$, with other bibliographic references.

84 We are not sure about the months corresponding to some of these ennaeteric festivals. So, we know that the Pythia took place during the so-called Boukatios, but there are some doubts about the month or months of the ennaeteric series Stepterion - Charila - Herois. The only attested fact is that the three ennaeteric festivals were celebrated кaтà тò $\dot{\epsilon} \xi \tilde{\eta} s$. Now, if it must be understood as "consecutively" in a strict sense, it would mean that they were developed from, say, the beginning of the Boukatios until the end of the Heraios. This solution runs up against the difficulty that the Herois (explained by a myth of the anodos of Semele) and the Charila (very close to the Athenian festival of the aiora, even because of the myth) are festivities more likely to belong to the Dionysiac months (winter).

85 See text in G. BONA, Pindaro. I Peani, Cuneo, 1988, p. 114 (the whole paean with commentary, p. 99-141).

86 The scholium to line 125 specifies that there was a sanctuary of Zeus Hellanios at Aegina, where they prayed $\pi \epsilon \rho l$ Toṽ aủxuoṽ. 
Another interesting point concerns the age of the singers. The refrain does not let many doubts that they are $\nu$ óo. The reason is clarified at the beginning of the song: that year was not possible to reunite a chorus of $\alpha \nu \delta \rho \epsilon s^{87}$. In my opinion, this was a decisive fact (though not the sole one) that conditioned the tenor of the whole composition, even the choice of the myth, as I will try to demonstrate now.

Unfortunately our information on the Tbeoxenia is scarce ${ }^{88}$ (and even more what we know about the Delphic ones). Nilsson rejected a primary Apollinean nature of this festivals, and he limited its scope in a first period to the family and the chtonic gods ${ }^{89}$. In the Dorian territories, for example, they are often dedicated to the Dioscuri ${ }^{90}$. But the Apollinean orientation increased with time. I suggest that the Delphic Theoxenia have had some influence on this process, because of its panhellenic nature.

Now an important point is to know if the different theoxenic festivals have a common significance, and which one is this. Once again our data are scarce, but there is a general agreement in acknowledging two relevant aspects: a funerary perspective ( $v i a$ the cult of dead) ${ }^{91}$ and a purificatory and/or expia tory function. Both (perhaps more the latter) are evident in the roman version, the so-called lectisternia, celebrated mainly in periods of pestilencies and other plagues to appease the gods ${ }^{92}$ (usually after consulting the Libri Sibyllini), and connected to funerary rites as well ${ }^{93}$. Two particular cases deserve some attention: in 218 b.C. they were dedicated to Juventus, whereas in 217 the rite was associated to a Saturnalia.

The nature of the paean, as a means of evil averting song, is suitable for a theoxenic frame. Pindar's Paean VI is not an isolated example: the "dionysiac"

87 See 1. 9. I fully agree with C.O. PAVESE, Il coro nel sesto Peana di Pindaro, in Tradizione e innovazione nella Cultura Greca da Omero all'Età Ellenistica (Scritti in Onore di Bruno Gentili), Roma, 1993, p. 469-479.

88 The basic data are in F. DENEKEN, De Theoxenits, Diss. Berlin, 1881; NILSSON, op. cit. (n. 19), p. 160-62; F. PFISTER, s.v. Theoxenia, in $R E$, V (1934), c. 2256-2258. The recurrence of related themes in myth has been analysed by D. FLÜCKINGER-GUGGENHEIM, Göttlicbe Gäste. Die Einkebr von Göttern und Heroen in der griechischen Mytbologie, Bern-Frankfurt-New York, 1984.

89 NILSSON, op.cit. (n. 19), p. 160.

90 NilsSON, op. cit. (n. 19), p. 417-421. DENEKEN, op. cit. (n. 88), p. 15 f. An interesting analysis of the theoxenia for the Dioscuri in Acragas as a frame for the celebration of an Olympic victory can be found in E. KRUMMEN, Pysos Hymnon. Festlicbe Gegenwart und mythisch-rituelle Tradition als Voraussetzang einer Pindarinterpretation, Berlin-New York, 1990, p. 217 f (see p. 223-228).

91 "Die grosse Ähnlichkeit dieser Totenfeiern mit den Opfern an Heroen und Götter bei Theoxenien springt in die Augen (...) Im Totenkultus also die Vorstellung von der Speisegemeinschaft mit jenseitigen Mächten wirklich von frühesten Zeiten an lebendig gewesen": so K. MEULI, "Griechische Opferbräuche", in Gesammelte Schriften II, Basel-Stuttgart, 1975, p. 919. Links among Dioscuri, dead cult, symposiac tradition and poetry (Simonides) have been studied by St. GOLDMANN, Statt Totenklage Gedäcbtnis, in Poetica, 21 (1989), p. 43-66.

92 See G. WISSOWA, Lectisternium, in RE, XII, 1 (1924), c. 1109-1115.

93 See WISSOWA, ibid, c. 1111, $21 \mathrm{f}$. 
paean by Philodamos of Scarpheia (4th century b.C.), and two more epigraphic texts (2nd century b.C.) were composed for the Delphic Theoxenia ${ }^{94}$. But, beside this aspect, we can realise a "mimetic" ability of this lyric genre to be adapted to the surrounding religious and social conditions, as Käppel has shown ${ }^{95}$. The Apollinean cult has an overwhelming side: the protection of youth, according to the ephebic nature of the god.

From my viewpoint an analysis of the Pindaric paean shows some of these features. However, it has at the same time a complexity of contents only explainable in a Delphic context. The main traits of this poem are:

a) The polarity (and complementariness) between Zeus and Apollo (from the initial invocations on) and their realms.

b) From the first lines on some crucial concepts are enhanced as well (explicitly or implicitly): youthfulness, freshness, newness (sometimes symbolised by the Graces and Aphrodite); the father (mother) - son links; the presence of the $\nu \epsilon^{\prime} \mathrm{ol}$, and so on.

c) The two foregoing traits are unified in the selected myth where we find:

- A kind of "dialectic" tension between the realms of Apollo and Zeus. It is a way of recreating the epic state of things (so is the case in the Iliad): Apollo protects the Trojans and Zeus tries to counterbalance the partial attitudes of the gods.

- A paradigm for mar̃ós and $\nu$ tol, the future young warriors. This paradigm (personified by Achilles and Neoptolemos) shows the contradictory sides of a warrior's life (and of a hero's as well).

- The epic colouring (very noteworthy in the language) emphasises the paradigmatic trend of the composition.

Some details of the myth contribute to the coherence of the whole poem. The theme belongs to the posthomeric epics, though modified by Pindar. The first mentioned event is the death of the great hero Achilles, under a version that harmonises the two ways of dying forseen for him in the Iliad (either in the hands of Apollo or of Paris and Apollo) ${ }^{96}$ : it is Apollo under the appearance of Paris who kills him. Achilles is described as a young and violent warrior, fighting against Hera and Athena and forcing the intervention of Apollo. The god

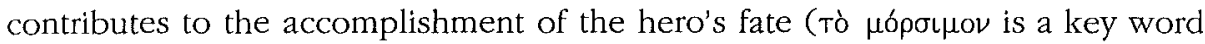
of this story ${ }^{97}$ ), but Zeus cannot stop the destruction of Troy. We may

94 L. KÄPPEL, PAIAN. Studien zur Geschicbte einer Gatung, Berlin-New York, 1992. 1 am referring to Paeans 39 (Philodamos), 45 and 46 of this edition.

95 See, for example, p. 227: "Die Strukturelle Kompatibilität dieses Festes mit der literarischen Gattung des Paian ist frappierend. Sie legt die Vermutung nahe, daß die Gattung des Paian an den Theoxenien durchaus ihren angestammten Ort hatte".

$96 \mathrm{ll}, \mathrm{XXI}, 278$ and XXII, $359 \mathrm{f}$.

97 Just as it will be again in the brief account of the death in $N$. VII, 44 (see above). 
confidently assume that the audience knew the post mortem destiny of Achilles (remembered some years later in the Olympian II), but instead of the expected end he makes his son Neoptolemos to appear on scene, to conclude Achilles' task. Neoptolemos' fate will be then the main motif. The poet uses his best stylistic and rhetorical resources (as, for instance, a remarkable perversion of the natural order of events) to enhance the death of Neoptolemos ${ }^{98}$. The poet underlines the "homoeopathic" justice illustrated by this myth: The death of the old Trojan king prevents Neoptolemos from reaching the old age and the crime committed beside the altar of Zeus Herkeios has its punishment in the Apollinean shrine. But the hero will find here a kind of immortalization (as did the father), after dying in the hands of the attendants of the temple, those who will be surveyed by himself thereafter. Neoptolemos is portrayed neither as a villain nor as an insane killer. He personifies a tendency of the whole myth in the poem: the enhancement of the figure of the young warrior and of the father-

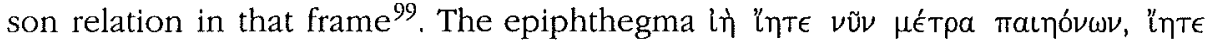
$\nu$ t́ol, following inmediatly the myth, marks a climactic point in the poem (underlined by procedures like biatus between strophes) ${ }^{100}$. It emphasises a culminant moment in the celebration: the commemoration of the death of the hero. This cry is then essential to implicate the audience as "age group": the v'́o, used to hear and learn by heart the epic songs, felt involved in the legends they were evoking with an old vocabulary adapted to the new music.

And what about Aegina and the Aeginetans? The last triad of the poem is very encomiastic for the island and its local heroes. Even some formal features contribute to a kind of "jumellage" of Delphi and Aegina: the symmetry of the invocations ${ }^{101}$, some rhetorical figures and images, and other subtle means (as to point out at the theoxenia the $\theta \in \mu\left(\xi_{\in} \in \nu \text { o } \alpha \rho \in \operatorname{Tá}^{\prime} \nu \text { of the island }\right)^{102}$. But the first motif that relates the island to Delphi is Zeus and his descendance, the Aeacids. It was not an easy task to harmonize the Thessalian, epic and Aeginetan traditions on Neoptolemos. Along the expansion period of this island from the 7th century on, Aegina appropriated the old Thessalian and Homeric heroes (Homer only knows Peleus and Achilles) and invented the myth of the

98 See, for instance, the cumulative use of 'Wiederholungsfigur', litotes and related figures (1. 105112).

99 The description of Neoptolemos as a 'double' of Achilles fits well the Pindaric version.

100 I. RUTHERFORD's proposes that Neoptolemos might be considered as a "second dragon" (Neoptolemos and the Paean-Cry: An Echo of a Sacred Aetiology in Pindar, in ZPE, 88 [1991], p. 1-10), because the epiphthegma alludes to the death of Python. Whatever the acceptance this suggestion may have, the intepretation the author gives of the moral implications of this cry is perfectly sound.

101 The chiastic order matches the initial invocation and that of the third triad through: a) the double epiclesis of Zeus (1.1 Olympios, 1. 125 Hellanios); the epithets accompaning the place names (see 1. 1-2 and 123-126).

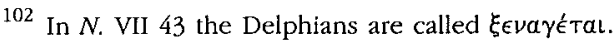


"autochthon" Myrmidons ${ }^{103}$. At the same time, the epic tradition has pervaded the Delphic ones (the case of Neoptolemos is a good evidence). Therefore Pindar's version is plenty of subtilities in order to satisfy all parts. Fehr, who describes the myths of this paean as a "high concentrated recapitulation of Iliad, Iliupersis and Nostoi" has pointed out rightly the originality of the Pindaric achievement, but he fails to understand the whole sense of the paean, as he states that Pindar has made a "cacology" of Neoptolemos, because the poet was not conditioned by the epinician conventions ${ }^{104}$. Much more important than the alleged negative aspects of Neoptolemos' behaviour is the presentation the poet makes of his whole life (and death): the accomplishment of fate and the intervention of Apollo, whose justice (and Zeus' too) is exalted.

However, to consider the Delphic myth of Neoptolemos from a positive outlook means to be conscious that it is a contextual appreciation: out of the Delphic environment, for example, the reminding of the death of Priamos might be felt by an Aeginetan as (at least) unsuitable. This is (I think) the reason why Pindar is obliged to clarify his words (but not to rectify them!) in Nemean VII. But, on the contrary, it is very reasonable to assume that the Pindaric paean and the nature of the celebration had a different effect on the Aeginetan attendants. In my opinion the presence of an Aeginetan theoria is undeniable ${ }^{105}$ (though it is not necessary to postulate that the chorus was composed by Aeginetans): they (and their fatherland) are openly praised, they shared divine and heroic traditions with the Delphians, and their great god (and ancestor) must have been an illustrious guest in this Theoxenia. Moreover, I think that Pindar's Paean VI might be a case for Mommsen's theory of the mixture of theoxenia and beroxenia at a given moment (pace Nilsson). Whatever it may be, Pindar assigns to Neoptolemos a precise function in the festival of the heroes: to be a

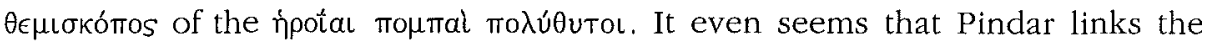
mythic event and the reality of the cult: the heroic pompe could be interpreted as a positive counterpart of Neoptolemos' visit to the sanctuary, when he came

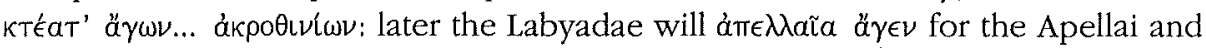

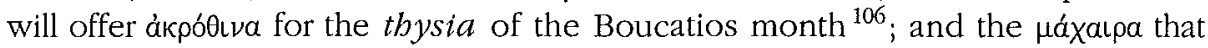
killed him is now the instrument of the actual thysiai.

\footnotetext{
103 See F. PRINZ, Grïndungsmythen und Sagenchronologie, München, 1979, p. 50 f.

${ }^{104}$ K. FEHR, Die Mythen bei Pindar, Diss. Zürich, 1936, p. 57.

105 A concise summary of the opinions on the Aeginetans' role in this ode is given by PAVESE, op. cit. (n. 97), p. 471, n. 3.

106 A 31, D 48.
} 


\subsubsection{The literary evidence: Heliodoros' Aitbiopica ${ }^{107}$}

This is a problematic evidence. As I have said above ${ }^{108}$, Nilsson thought that it was not a reliable testimony, because we cannot know the exact amount of phantasy that the narrative involves ${ }^{109}$. The opposite attitude is represented, among others, by Fontenrose, who trust Heliodoros nearly without hesitation: "The sacrifice, with its procession, was a regular feature of the Pythian festival. Instituted by the Aenianes, a prominent Amphictionic people, it became an integral part of Delphic worship" ${ }^{110}$. I think that Nilsson's suspicions go too far. However, some caution is indeed necessary, due to the fictional nature of our source. It is the plot that conditions the situations. For example, the description of the meeting of Theagenes and Charicleia (the boy as Apol linean architheoros and the girl as zakoros of Artemis, -and as living Artemis) has apotheosic tints and arouses suspicions about the fidelity of some features. But consider these details:

- Although the quadriennial periodicity of the panegyris could have been an invention of the author (to establish a simultaneity with the Pythian games), it may correspond to an actual tradition of the Thessalians for the same reason: to send their youths and girls to the great panhellenic Apollinean festival, because it was an important occasion to renew the ancient links between their genos and Delphi, thinking of the epbebic (and initiatic) atmosphere of the cults.

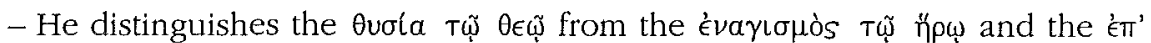

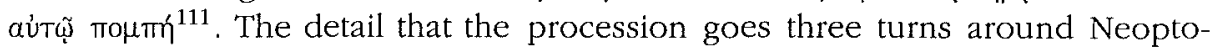
lemos tomb before the sacrifice begins might be authentic.

- At some moments it seems that a real evidence on the enagismos is ming-

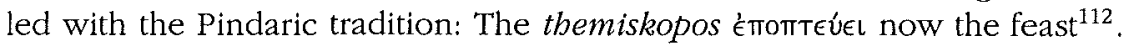

- The girls sing hymns to Thetis and Peleus. It can seem a mere invention (in accordance with the alleged epic ascendance of the Aenianes), but it fits Thessalian religion and mythology ${ }^{113}$.

- Last, but not least: the young age of the attendants: epbeboi and korai. They are not adult pilgrims. Despite the fact that the narrative frame may have conditioned this choice, I suggest that it is a consequence of the initiatic and ephebic ideology created around Neoptolemos and Apollo's cults.

\footnotetext{
107 II, 34 -3, 6.; III, 10. See above 2.

108 See above.

109 See above n, 19

110 FONTENROSE, Neoptolemos, p. 196. However, he recognises some fictional compounds: see ibidem, n. 17 on "Heliodoros' fiction" (Aitb., IV, 20 f.).

111 II, 34-35.

112 III, 10. Already realised by FONTENROSE, Neoptolemos, p. 197.

113 Cf. P. PHILIPPSON, Thessalische Mythologie, Zürich, 1944, p. 137 f.
} 
Moreover, it is not the sole relation between the Aenianes and Delphi, on the one hand, and on practices of the Apollinean religion on the other. Across their country passed the Delphic pompê of the Doloneia and, though they had left their original region in Thessaly, their myths supported these origins. Some of these legends, preserved by Plutarch ${ }^{114}$, involve rituals of the pharmakos type ${ }^{115}$. Every year they drove a bull out of the country, while singing a song forbidding it to come back; furthermore, they had stoned their king Oinoclos, he who had led them to Kirra, following an Apollinean oracle in a period of drought, and so the plague was over. Now, Bremmer has observed that there is a connection between the pharmakos rites, the seasonal renewal and the growth of the adolescents ${ }^{116}$. In some religious calendars the New Year festival is preceded by a month full of purification rituals ${ }^{117}$.

Then the traditions about the Aenians form an interesting "Apollinean" pattern: ephebic and purificatory rituals as substantial ingredients of their religious life. Under this frame Neoptolemos cult makes full sense (and much more in a Delphic surrounding): he fits in a large measure the pbarmakos type (while retaining the heroic traits), he is an epbebic model and presides over the sacrifices and rituals, near the temple of the god of the renewal, the patron of youth and purifier par excellence. And he also represents the link between the epic traditions and the ancient Thessalian religion and legends.

\section{Summing up}

I will give now a summary of the main conclusions I think we may draw from the precedent reflexions.

a) I think that the link between myth and cult is very tight. They must have existed at Delphi since an ancient date, A priori this link neither precludes nor presuposes a periodic and changeless ritual before 278 b.C., but the evidence shows that both, myth and cult, have a deep assimilation and adaptation to the beortological frame in both aspects: ideology and function. Under these conditions, it is more than reasonable to expect some kind of ritual tradition and regular cult.

b) The theory of the existence of a previous cult of a ancient hero called Pyrrhos, then replaced by Neoptolemos', is difficult to support without the possibility of settling an archeological and/or historical base. The alleged

${ }^{114}$ Qu. gr., 293f-294c and 297b-c.

115 See W. BURKERT, Structure and History in Greek Mytbology and Ritual, Berkeley, 1979, p. 65-66 and $c f$. C. MIRAlLes - J. POrtulas, The Poetry of Hipponax, Roma, 1988, p. 40-41. If these authors are right in relating the Hipponactean testimony to the Delphic traditions on the Aenians and the Doloneia, then the Ionian poet gives us an ancient terminus ante quem for these cults.

116 J. BREMMER, Scapegoat rituals in Ancient Greece, in HSCPb, 87 (1983), p. 299-320 (319-320).

117 Ibidem, p. 320. 
Mycenaean origin is only sheer speculation and has a weak archaeological support.

c) The testimony of Pindar and Heliodoros may allow us to postulate a complex (but familiar) pattern that subsumes such functions as purification and renewal (seasonal and civic, the latter cristallysed in the ephebic features of both, the hero and the participants), together with the enhancement (and defense) of local (sacrificial) practices ${ }^{118}$.

d) It is not easy to locate this cult in the Delphic calendar (see infra under f). Mommsen postulated a penteteric beroxenia, according to Heliodoros' account. A possibility is the Theoxenia (it does not exclude a quadriennial celebration like that of the Aenians either). The reason is that in this feast converge elements of dead, hero, and god cult, and that according to Pindar's Paean VI an ephebic perspective could be postulated. But it is possible too that Pindar had given this outlook to the poem to adapt it to the unusual age of the singers in that very year.

e) The inscription of the Labyadae does not mention Neoptolemos, but we find a coherent annual cycle, beginning in a 'Neujahrfest' with different offerings according to the "age group" and adapted to the seasonal changes, reserving the months for the different divinities and heroes more suitable for each period of the year: the gods (and perhaps heroes) of the phratria at the beginning (Apollo, Zeus Poseidon, Hera), Dionysos in winter (and maybe other daimones), the Birth of Apollo anticipating the beginning of the spring, and the festivities of Artemis inmediatly after it; then comes the theoxenia with its underlining of this renewal (perhaps with the attending of some heroes) and the spring and summer celebrations devoted to other semidivine or divine entities (Dioscuri, Heracles and so on). They do not mention Neoptolemos. To explain this fact four reasons may be aduced: 1) At this time there was no cult at all devoted to this hero. 2) There was no annual festivity: the quadriennial or ennaeteric are not recorded on this document. 3) It is not recorded because he is not felt as, properly speaking, a hero of the Labyadae. 4) It was not necessary to mention it, because everybody knew that his cult was a part of other (mentioned) rites. I confess that we have no cutting data to take a decission, but I personally feel less inclined to accept 1 ).

f) To postulate a primitive stage, to which should be assigned the agrarian and other traits (dead cult, purification, etc.) is, as I have said above, difficult to demonstrate (historically speaking). It is even possible that, rather than a primitive layer, we should postulate an ideological frame (diachronically pervasive), compatible with other features. It is a matter of fact that both, myth

\footnotetext{
118 We may wonder if these aspects correspond to different layers: an original pharmakos rite, then adapted to the dead and hero cult and eventually transformed in a great panhellenic cult with ephebic connotations. But this would be again sheer speculation if we do not establish a firm historical fundament.
} 
and cult (as many Delphic traditions), denote the Thessalian influence, well attested at different moments, but more relevant in the 7 th century b.C. It is not an isolated case, since the stepterion ritual links Delphi with those northly regions (like its mythic cognate, the Hyperborean way). But both, myth and cult, show (from an early date too) the panhellenic tendency that characterises the epic tradition and the development of the Delphic sanctuary. Some stages may be postulated. The Aeginetan and Cnidian implications in this tradition are in accordance to the trend I have just designed, and are representatives of the state of affairs in the, say, 6th and 5th centuries (especially after 490). The Labyadae inscription offers a more local perspective, but in accordance with the main trends we have detected. Then comes a 'dark age', until the establishment of the yearly enagismos in 278: an absence of periodical timai to the hero should not be descarded for the previous time, but perhaps it was only a lack of regular cult. However, it remains the suspicion that the Aenianes could have preserved (or perhaps recovered at a given moment) an old tradition. If the suggestion advanced by Miralles and Portulas were right ${ }^{119}$, then the ritual and epic bonds between Aenians and Delphic rites would be attested at least from the 6th century. Anyway the links between Aenians and Delphi, as well as the reality of a quadriennial theoria with an ephebic representation appear very probable.

g) The cult and myth of Neoptolemos at Delphi is an exceptional example of the particular religious, social, and historical characteristics of this sanctuary: they share general traits with myth and ritual complexes well attested along the ancient Greek world (agrarian elements, dead and hero cult, purificatory and renewing aims, epic influence, ephebic and more general initiatic trends), but some of these traits show at the same time the adaptation to the Delphic surrounding: particular sacrificial features, panhellenic perspective of the cult (the hero cult is usually a local one).

A relevant case for a multidisciplinary approach in the field of Greek religion.

Emilio SUÁREZ DE LA TORRE

Departamento de Filología Griega

Facultad de Filosofía y Letras

Universidad de Valladolid

E - 47002 VALLADOLID

119 See above n. 115. 